\title{
Role of nematodes in decomposition processes: Does within-trophic group diversity matter?
}

\author{
Ilse De Mesel ${ }^{1, *}$, Sofie Derycke ${ }^{1}$, Jean Swings ${ }^{2,3}{ }^{,}$Magda Vincx $^{1}$, Tom Moens ${ }^{1}$ \\ ${ }^{1}$ Marine Biology Section, Biology Department, Ghent University, Krijgslaan 281 (S8), 9000 Ghent, Belgium \\ ${ }^{2}$ Laboratory of Microbiology, Ghent University, KL Ledeganckstraat 35, 9000 Ghent, Belgium \\ ${ }^{3} \mathrm{BCCM}^{\mathrm{TM}}$ /LMG Culture Collection, Laboratory of Microbiology, Ghent University, KL Ledeganckstraat 35 , \\ 9000 Ghent, Belgium
}

\begin{abstract}
The importance of biodiversity for the functioning of ecosystems is still very unclear. Many hypotheses, mainly based on terrestrial studies, have been formulated, focussing on the plant diversity-productivity relationship. In this study, diversity-related and species-specific effects of bacterivorous nematodes on the decomposition rate of cordgrass detritus Spartina anglica and on the associated microbial community were investigated using laboratory microcosm experiments. Four bacterivorous nematode species (Diplolaimelloides meyli, Diplolaimelloides oschei, Diplolaimella dievengatensis and Panagrolaimus paetzoldi) were added either separately or in combinations of 2 or 3 species to the microcosms. In contrast with previous reports, no stimulation of the decomposition process was observed in the presence of nematodes. Still, clear differences in process rates were found between nematode treatments. $P$. paetzoldi, reaching considerably higher densities than the other nematode species, suppressed bacterial activity and diversity, probably due to overgrazing. This was, however, not translated into slower decomposition. Within treatments exclusively containing monhysterid nematode species (D. meyli, D. oschei and $D$. dievengatensis), differences in microbial activity and decomposition rates were found, but again no link was observed between activity and decomposition. Our data did not support any hypothesis predicting enhancement of process rates with an (initial) increase in numbers of nematode species, or redundancy among the studied species. Rather, we obtained support for an idiosyncratic diversity model, as differences in the effect of bacterivore nematode species and species combinations could not be predicted at the start of the experiment. This could be explained by the inhibitory interactions between nematode species.
\end{abstract}

KEY WORDS: Functional diversity · Idiosyncratic biodiversity model $\cdot$ Bacterivorous nematodes · Spartina decomposition

Resale or republication not permitted without written consent of the publisher

\section{INTRODUCTION}

The role of biodiversity in the functioning of ecosystems has been discussed extensively over the past few decades. Many studies have concentrated on terrestrial systems with particular emphasis on the link between plant diversity and productivity (Loreau et al. 2001, Tilman et al. 2001). These results have led to a number of hypotheses, which generally describe a predictable consequence of altering biodiversity (Schläpfer et al. 1999). The extremes range from no effect of diversity, as predicted by the (modified) null hypothesis, to an improvement of ecosystem function- ing each time a species is added to the system, referred to as the rivet hypothesis (Ehrlich \& Ehrlich 1981). Of particular interest is the redundancy hypothesis (Walker 1992), which states that it is of major importance that all functions within an ecosystem are fulfilled and that species within a functional group are thought to be redundant. This does not exclude, however, the possibility that ecosystem stability may benefit from within-functional group diversity, as their different responses to environmental factors may allow persistence of the ecosystem function after disturbance (Walker 1995, Naeem 1998). In contrast to the previous hypotheses, the idiosyncratic model suggests that 
altering biodiversity generally affects ecosystem functioning, but in an unpredictable manner (Lawton 1994) as a result of a general lack of understanding of the complex and often subtle interactions between species within and across functional groups (Lawton 1994, Emmerson et al. 2001, Postma-Blaauw et al. 2005).

Fewer studies up to now have investigated the importance of diversity in other ecosystem processes, such as decomposition. Decomposition is mainly a microbial process and can be affected by higher trophic levels. Bacterial grazers, such as protozoans and nematodes, have often been found to stimulate bacterial activity and decomposition processes (e.g. Findlay \& Tenore 1982, Freckman 1988, Alkemade et al. 1992a,b, Griffiths 1994, Mamilov et al. 2000).

We conducted a microcosm study with 4 estuarine nematode species from a single trophic or functional group-bacterivores - as a model to study withinfunctional-group redundancy. The decomposition of cordgrass Spartina spp., often the dominant vegetation in salt marshes (Howarth 1993), was the ecosystem function of interest. The effect of Diplolaimelloides meyli, Diplolaimelloides oschei, Diplolaimella dievengatensis and Panagrolaimus paetzoldi, all commonly found and often co-occurring on decaying cordgrass in the Paulina Salt Marsh (Westerscheldt, The Netherlands) (T. Moens pers. comm.), was investigated separately and in combination treatments. The former 3 species belong to the Monhysteridae; the latter belongs to the Panagrolaimidae. These nematode families are typically associated with decomposing plant detritus in aquatic sediments (Warwick 1987). In general, between 10 and 20 nematode species co-occur on cordgrass detritus (I. De Mesel \& T. Moens pers. obs.), but Alkemade et al. (1993) found that only 5 species were positively correlated with decomposition rates.

Analysis of the monospecific treatments has shown some species-specific effects, mainly on the bacterial community structure (De Mesel et al. 2004) and activ-

Table 1. Overview of the treatments

\begin{tabular}{|lcl|}
\hline $\begin{array}{l}\text { Treatment } \\
\text { code }\end{array}$ & $\begin{array}{c}\text { Number of species } \\
\text { (i.e. diversity level) }\end{array}$ & \multicolumn{1}{c|}{ Nematode species } \\
\hline A & 1 & Diplolaimelloides meyli \\
B & 1 & Diplolaimelloides oschei \\
C & 1 & Panagrolaimus paetzoldi \\
D & 1 & Diplolaimella dievengatensis \\
E & 2 & D. meyli, D. oschei \\
G & 2 & D. meyli, D. dievengatensis \\
I & 2 & D. oschei, D. dievengatensis \\
J & 2 & $P$ paetzoldi, D. dievengatensis \\
L & 3 & D. meyli, D. oschei, D. dievengatensis \\
N & 3 & D. meyli, P. paetzoldi, D. dievengatensis \\
S & 0 & No nematodes \\
\hline
\end{tabular}

ity (De Mesel et al. 2003), and to a lesser extent also on the decomposition rate (De Mesel et al. 2003). Here, we focus on the effects of pooling 2 or 3 nematode species. We tested (1) whether species-specific effects observed in the monospecific treatments were maintained in the presence of other species and (2) whether there was any diversity-dependent effect on (i) the decomposition rate, (ii) microbial activity and (iii) bacterial diversity.

\section{MATERIALS AND METHODS}

Experimental set-up. The experimental set-up has been described in detail in De Mesel et al. (2003). Briefly, green cordgrass Spartina anglica leaves were collected in the Paulina Salt Marsh (Westerscheldt, The Netherlands). The chemical composition was very similar in all leaves ( $\mathrm{C}$ and $\mathrm{N}$ content were, respectively, about 42 and $2 \%$ ). In the laboratory, the leaves were cleaned with ethanol $(70 \%)$ and sterile artificial seawater (ASW) (Dietrich \& Kalle 1957). The leaves were cut into fragments, and $1.9 \pm 0.2 \mathrm{~g}$ (wet mass) was put in Petri dishes (90 mm diameter) on sterile sediment saturated with ASW with a salinity of 20 psu. A natural microbial inoculum was obtained by mixing sediment, habitat water, fresh and decomposing cordgrass leaves and agar from the nematode cultures (Moens \& Vincx 1998). This microbial inoculum was filtered over Whatman GF/C filters $(1.2 \mu \mathrm{m}$ pore diameter) to remove flagellates and other small eukaryotes. All Petri dishes were inoculated with $2 \mathrm{ml}$ of this suspension. After a $24 \mathrm{~h}$ incubation, nematodes were added to the microcosms.

Four nematode species commonly found on decaying cordgrass in the Paulina Salt Marsh (T. Moens pers. comm.) were selected for this experiment: Diplolaimelloides meyli, Diplolaimelloides oschei, Diplolaimella dievengatensis and Panagrolaimus paetzoldi. All species were applied separately to the microcosms (De Mesel et al. 2003), and in random combinations of 2 and 3 species. Each time, 36 individuals were inoculated in the microcosms $(2 \times$ 18 in treatments with 2 species; $3 \times 12$ in treatments with 3 species). An overview of the treatments is given in Table 1.

Microcosms were incubated under controlled conditions in the dark at $20 \pm 2^{\circ} \mathrm{C}$. Three replicate microcosms per treatment were destructively sampled after each of the following incubation times: 10, 20, 30, 40, 50, 65 and 75 d. Microbial activity (respiration 
rate and enzymatic activity) and decomposition parameters (mass, carbon and nitrogen content) were measured at each sampling; nematode densities and bacterial diversity were analysed on Days 30, 50 and 65.

Decomposition rate. On every sampling occasion, leaves were dried in the air and weighed. An exponential link between wet mass and dry mass was found, allowing the calculation of dry mass values (De Mesel et al. 2003). Percentage $C$ and $N$ in the cordgrass leaves was determined with a Carlo-Erba element analyser Type NA-1500 and converted to absolute amounts; $\mathrm{C}$ and $\mathrm{N}$ contents of the detritus were expressed in milligrams.

Nematodes. Nematodes were sampled from the leaves by shaking the detritus in a receptacle with ASW and were extracted from the sediment by centrifugation with Ludox (Heip et al. 1985). After staining with Rose Bengal, they were counted and, in the combination treatments, identified under a dissecting microscope.

Microbial activity. The microbial community attached to the cordgrass leaves was collected by intensely shaking the leaves in a receptacle with sterile ASW (50 ml). Although a small fraction of the microbial community might not have been removed from the litter, the standardised procedure allows comparison between treatments. Respiration rate of the microbial community was measured with a Strathkelvin 928 6-channel Dissolved Oxygen System to assess total microbial aerobic activity; $1 \mathrm{ml}$ sub-samples were transferred to a measuring unit. The oxygen concentration in the suspension was measured at $20^{\circ} \mathrm{C}$ for approximately $30 \mathrm{~min}$. Respiration rates $\left(\mu \mathrm{mol} \mathrm{O}_{2} \mathrm{~h}^{-1}\right.$ ) were calculated from the slope of the regression of oxygen concentration versus time. The EnzCheck Protease Assay Kit E6638 for green fluorescence (Molecular Probes) was used to measure the proteolytic activity of the microbial community; $100 \mu \mathrm{l}$ sub-samples were incubated with fluorescently labelled casein for $30 \mathrm{~min}$ in the dark. The fluorescent labels, which were released after hydrolysis, were then measured with a Victor multilabel counter using excitation and emission wavelengths of 505 and $513 \mathrm{~nm}$, respectively. Readings were performed at $25^{\circ} \mathrm{C}$.

Bacterial diversity. An assessment of bacterial diversity was made based on DGGE (Denaturing Gradient Gel Electrophoresis) banding patterns of the $\mathrm{V} 3$ region of the 16S rDNA genes. The protocols used for DNA extraction and purification, amplification of the fragments and the DGGE analysis have been described in detail in De Mesel et al. (2004). The banding patterns were analysed with the software package Bionumerics 5.1 (Applied Maths BVBA). An optical density profile through each lane (corresponding to a single sample) identifies band positions and calculates the percent contribution of the intensity of each band (representing 1 operational taxonomic unit, OTU) to the total intensity of the lane. For a discussion of the advantages and shortcomings of this technique, we refer to De Mesel et al. (2004) and references therein.

In analogy with the results presented in De Mesel et al. (2004), bacterial diversity is expressed as the Shannon-Wiener Index $\left(H^{\prime}\right)$, based on relative band intensities (Magurran 1988):

$$
H^{\prime}=\sum_{i=1}^{n} p_{i} \ln p_{i}
$$

where $n$ represents the number of bands in the sample, and $p$ the relative intensity of the $i$ th band.

Statistical analysis. To evaluate the importance of nematode diversity on the decomposition rate $(\mathrm{N}$ and $\mathrm{C}$ content), microbial activity (respiration rate) and bacterial diversity, a nested analysis of variance (ANOVA), in which treatments (i.e. species and species-combinations) were nested within diversity levels (i.e. Levels 0, 1, 2 and 3 referring to 0, 1, 2 and 3 nematode species, respectively), was performed by means of the GLM module in the Statistica software package. The time factor was also integrated into the analysis. The output of the nested ANOVA provided information on the effect of diversity and on the effect of time, and indicated if differences were found between treatments nested within a diversity level. Due to the unbalanced design of the experiment, the combined effect 'diversity $\times$ time' could not be tested with the Statistica software. When ANOVA indicated significant differences, the Tukey HSD (Honestly Significant Differences) test was used for pairwise post hoc comparisons. Respiration rate was 4th-root-transformed, $\mathrm{N}$ content was square-root-transformed and $\mathrm{C}$ content was log-transformed to meet the required assumptions; no transformation was required for bacterial diversity. The data on enzymatic activity did not fulfil the assumptions for nested ANOVA, even after transformation. No non-parametric alternative could be applied for a similar analysis.

Species- or combination-specific effects were tested by means of a 2-way ANOVA, in which the effects of treatment, time and the combined effect of treatment and time were tested. When the overall test was significant, a Tukey HSD post hoc test was used for pairwise comparisons. C content and respiration rate were logtransformed, and proteolytic activity was square-roottransformed to meet the required assumption. A transformation of $\mathrm{N}$ content was not necessary.

While counting the nematodes, it became obvious that monhysterid densities reached in combination treatments were lower than in monospecific treatments (see 'Results'). We tested the significance of these differences by means of 2-way ANOVA, includ- 
ing the effects of time and treatment. This test was run on total nematode densities and on species-specific densities in those treatments containing exclusively monhysterid species. Again, a Tukey HSD post hoc test was used for pairwise comparison. Densities were logtransformed to meet the required assumptions.

\section{RESULTS}

\section{Nematodes}

Nematode densities in all treatments with Panagrolaimus paetzoldi were 10 to $10^{3}$ times higher than in
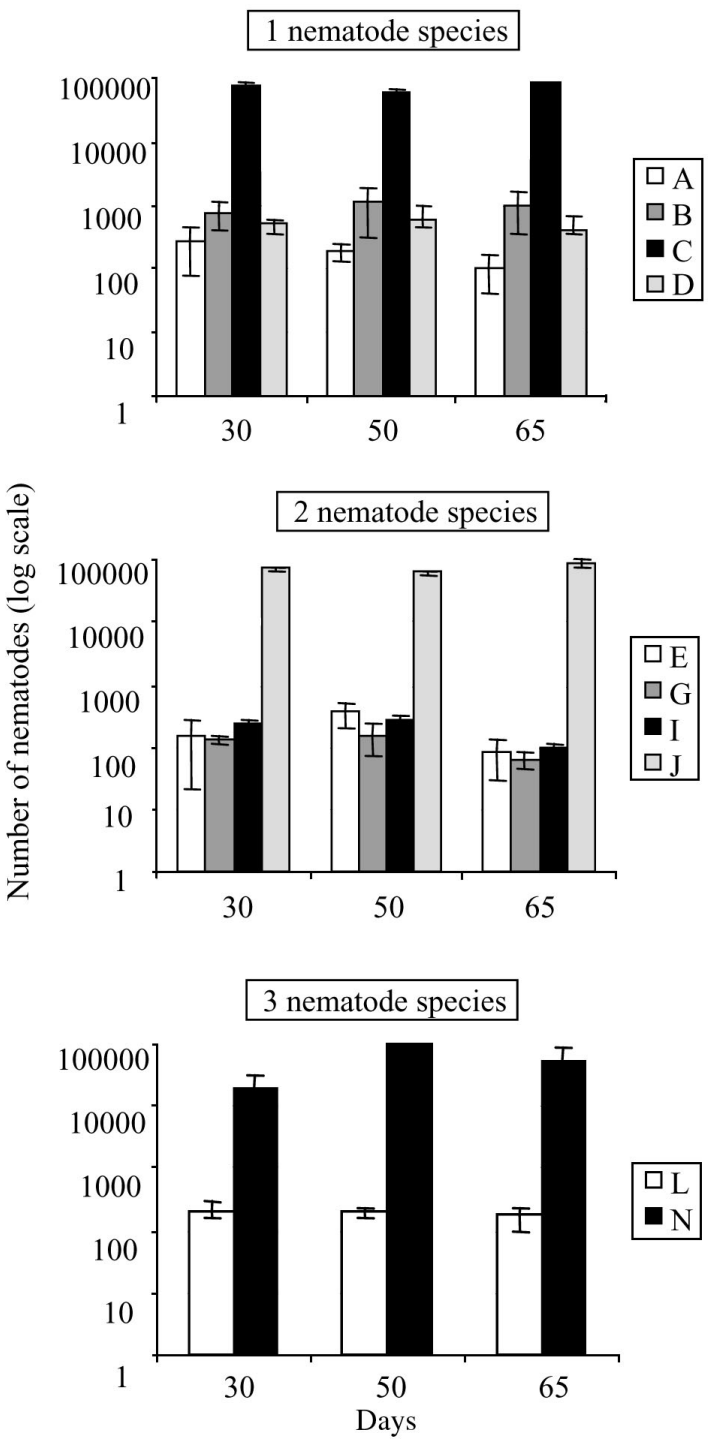

Fig. 1. Total nematode densities per microcosm in the monospecific treatments and the combination treatments (log scale) (average of 3 replicates $\pm 1 \mathrm{SE}$ ). Treatment codes are given in Table 1 other treatments (Fig. 1). In the combination treatments this was solely due to the high numbers of $P$. paetzoldi; the monhysterids made up only a minor part of the total nematode numbers. In general, high variability among replicates was observed.

Nematode densities clearly differed between treatments containing only monhysterid nematode species (Fig. 2). Due to the considerably higher densities of Panagrolaimus paetzoldi, these differences were not revealed in any statistical test that included all treatments. Therefore, a 2-way ANOVA on species-specific densities in treatments containing only monhysterid nematodes was carried out. Total nematode densities and species-specific densities differed significantly among treatments (total densities: $F_{6,40}=5.01 ; \mathrm{p}<$ 0.001; Diplolaimelloides meyli: $F_{3,24}=5.30$; $\mathrm{p}<0.01$; Diplolaimelloides oschei: $F_{3,24}=12.04 ; \mathrm{p}<0.001$; Diplolaimella dievengatensis $\left(F_{3,24}=9.68 ; \mathrm{p}<0.001\right)$ (Fig. 2). Densities of D. oschei were significantly higher in the monospecific treatments compared to all combination treatments (for all pairwise comparisons $\mathrm{p}<$ 0.01). For $D$. dievengatensis, densities were significantly higher in the monospecific treatment than in combination treatments with $D$. meyli $(\mathrm{p}<0.001)$ and with both $D$. meyli and $D$. oschei $(\mathrm{p}<0.01)$. For $D$. meyli, densities in the monospecific treatments were only significantly higher compared to the 3-species combination $(p<0.01)$. Although a trend of higher total densities in the monospecific treatments than in the combination treatments was observed (Fig. 2), only differences between Treatment B (D. oschei) and, respectively, Treatment E (D. meyli + D. oschei) and Treatment $\mathrm{G}(D$. meyli $+D$. dievengatensis $)$ were significant (both $\mathrm{p}<0.01$ ).

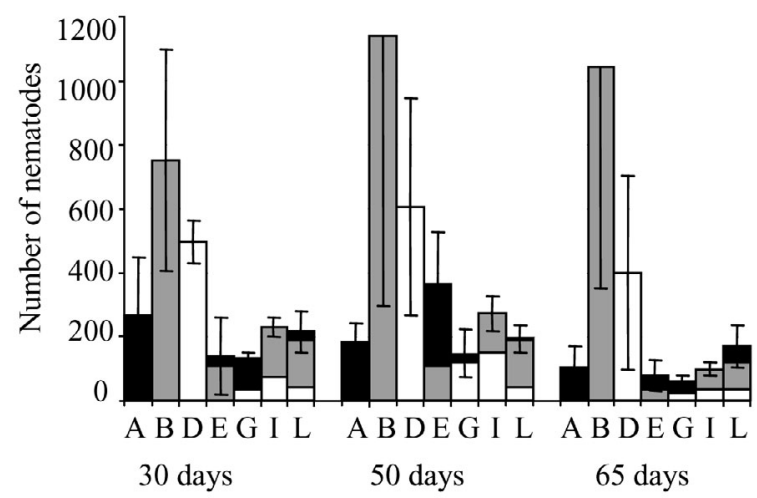

Fig. 2. Diplolaimelloides meyli, Diplolaimelloides oschei, Diplolaimella dievengatensis. Nematode densities per microcosm in treatments containing exclusively monhysterid species (average of 3 replicates $\pm 1 \mathrm{SE}$ ). Treatment codes are given in Table 1 


\section{Microbial activity}

Respiration rate

Overall, respiration rate was high at the beginning of the experiment, but decreased rapidly over time. A significant difference in respiration rate between diversity levels (nested ANOVA: $F_{3,214}=5.86, \mathrm{p}<$ 0.001) and treatments (2-way ANOVA: $F_{10,154}=7.63$, $\mathrm{p}<0.001$ ) was found. Respiration rate was significantly higher in the control treatment (diversity level $=0$ ) than in all other diversity levels $(\mathrm{p}<0.05, \mathrm{p}<0.01$ and $\mathrm{p}<0.05$ for Diversity Levels 1, 2 and 3, respectively; Fig. 3). Within diversity levels, respiration rate was significantly higher in Treatment A (Diplolaimelloides meyli) than in Treatment C (Panagrolaimus paetzoldi) ( $\mathrm{p}<0.01)$, and for the 2-species combinations in Treatment G (D. meyli and Diplolaimella dievengatensis) than in Treatment I (Diplolaimelloides oschei and D. dievengatensis) $(\mathrm{p}<0.05)$. Only the significantly higher respiration rate in the control than in the 2species level was largely confirmed (significant differences for 3 combinations out of 4 ) by Tukey HSD test following 2-way ANOVA. No consistent species-specific effects were observed.

\section{Proteolytic activity}

Within the nematode treatments, the overall trend was a slight increase in enzymatic activity with increasing nematode diversity during the first part of the experiment, but, after $30 \mathrm{~d}$, this relation had disappeared. The activity in the control was situated in between the other treatments (Fig. 4).

Within each diversity level, enzymatic activity was reduced when Panagrolaimus paetzoldi was present, with most differences being significant (overall treatment effect in 2-way ANOVA: $\left.F_{10,132}=12.27, \mathrm{p}<0.001\right)$.

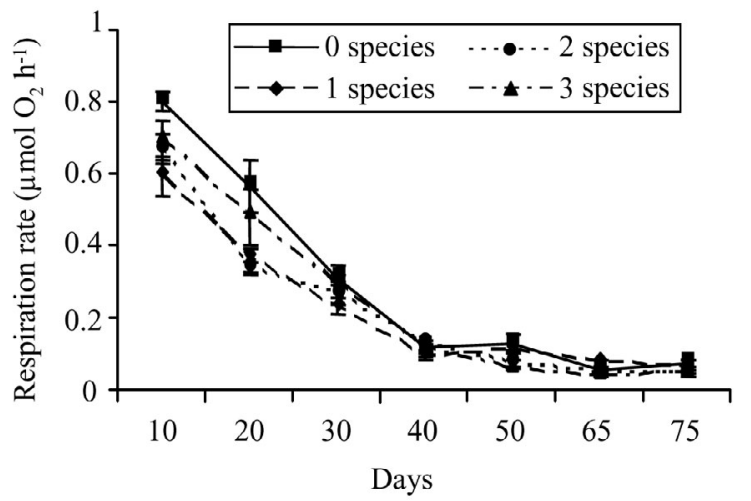

Fig. 3. Average respiration rate $( \pm 1 \mathrm{SE})$ per diversity level on each sampling occasion

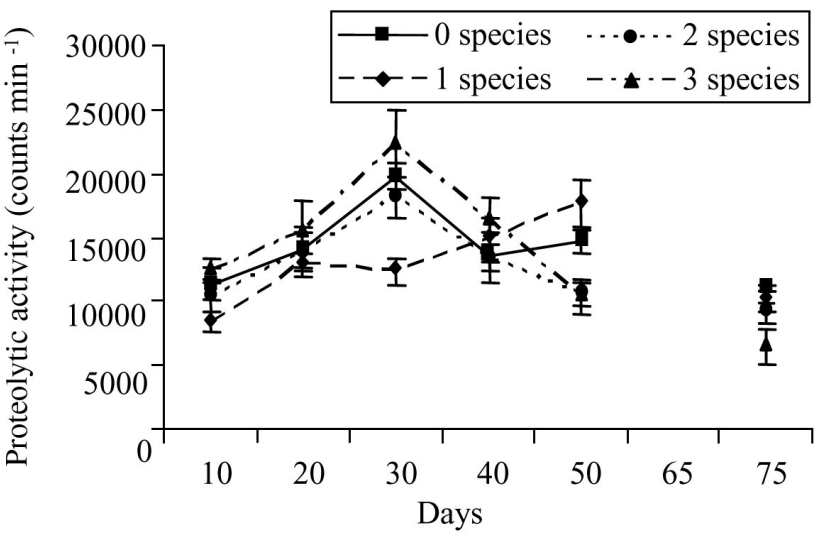

Fig. 4. Average proteolytic activity $( \pm 1 \mathrm{SE})$ per diversity level on each sampling occasion

\section{Bacterial diversity}

The number of OTUs in the microcosms was within the range observed in natural systems (I. De Mesel pers. obs.). There was generally a lower bacterial diversity (expressed as the Shannon-Wiener Index) in the combination treatments than in the monospecific treatments and, to a lesser extent, in the control (Fig. 5). Only the differences between Diversity Level 1 and the 2- and 3-species combinations were statistically significant (overall diversity-related effect in nested ANOVA: $F_{3,70}=10.31, \mathrm{p}<0.001$; pairwise comparisons, respectively, $\mathrm{p}<0.01$ and $\mathrm{p}<0.001$ ). Although a significant difference between treatments within diversity levels was indicated $\left(F_{6,70}=4.61, \mathrm{p}<0.001\right)$, no pairwise differences were revealed in the Tukey HSD post hoc test. Within diversity levels, however, the treatments containing Panagrolaimus paetzoldi generally had a lower bacterial diversity. For the 3 -species combination, and, to a lesser extent, the 2-

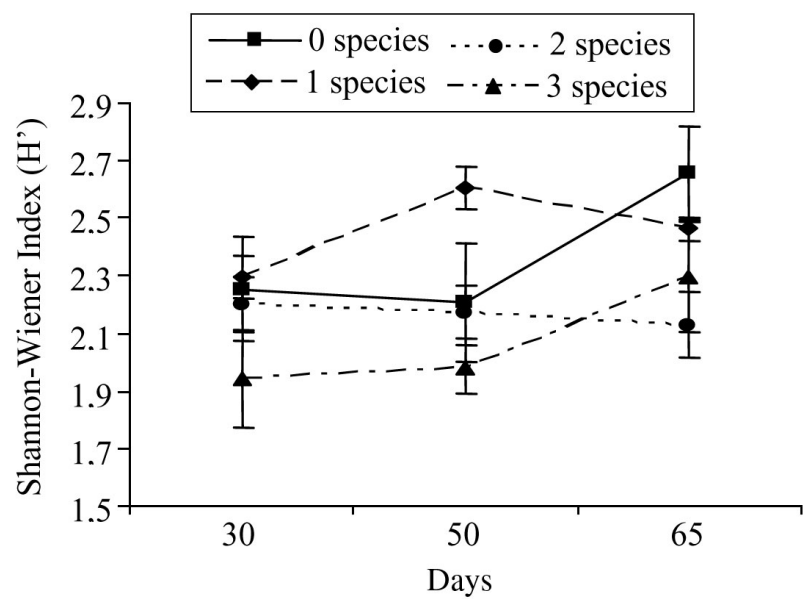

Fig. 5. Average bacterial diversity $( \pm 1 \mathrm{SE}$ ) per nematode diversity level at each sampling occasion 
species combination, the lower bacterial diversity in the presence of $P$. paetzoldi compared to other treatments was confirmed by significant pairwise differences in the post hoc comparison following 2-way ANOVA (overall treatment effect: $F_{9,60}=10.63, \mathrm{p}<$ 0.001).

Unfortunately we failed to analyse bacterial diversity in the combination treatment with Diplolaimelloides meyli and Diplolaimella dievengatensis.

\section{Decomposition rate}

C content

A significantly higher $\mathrm{C}$ content in the treatments with the 2-species combinations than in other diversity levels was seen (overall diversity effect in nested ANOVA: $F_{3,214}=19,30, \mathrm{p}<0.001$; all pairwise comparisons: $\mathrm{p}<0.001$; Fig. 6). Also a significantly higher $\mathrm{C}$ content in the 1-species diversity level than in Diversity Level 0 (controls) was found ( $p<0.05)$. Only the differences between the 2-species combinations and the control were clearly confirmed by the post hoc test after 2-way ANOVA (overall treatment effect: $F_{10,154}=$ 8.36, $\mathrm{p}<0.001$; all pairwise comparisons: $\mathrm{p}<0.001)$. No species-specific effects on $\mathrm{C}$ content were found.

\section{$\mathrm{N}$ content}

Significant differences for $\mathrm{N}$ content among diversity levels $\left(F_{3,214}=5.93, \mathrm{p}<0.001\right)$ were found. $\mathrm{N}$ content in the control treatment was significantly lower than in nematode treatments (significance level with Diversity Levels 1, 2 and 3, respectively, p $<0.05, \mathrm{p}<0.05$ and $\mathrm{p}<0.001$; Fig. 7). Within diversity levels $\left(F_{7,214}=8.96\right.$, $\mathrm{p}<0.001), \mathrm{N}$ content in the monospecific Treatment D (Diplolaimella dievengatensis) was significantly

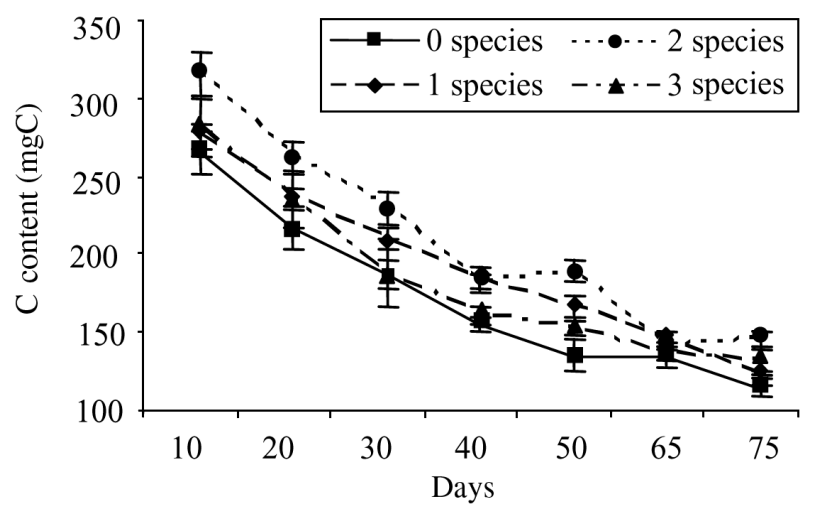

Fig. 6. Average $\mathrm{C}$ content $( \pm 1 \mathrm{SE})$ of the detritus per diversity level

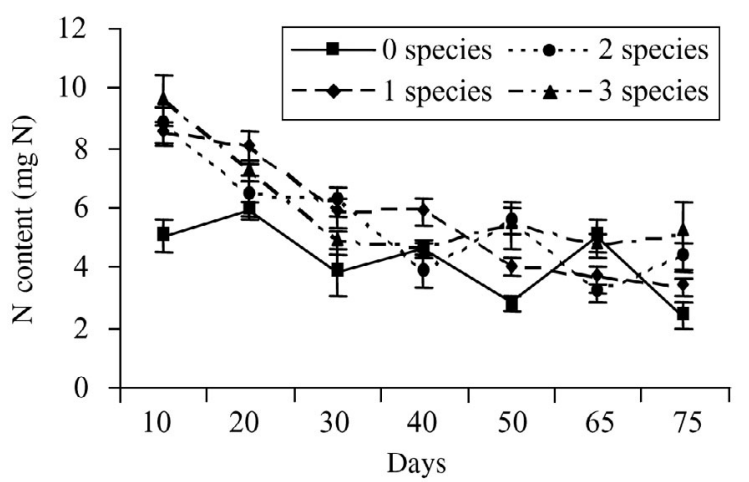

Fig. 7. Average $N$ content $( \pm 1$ SE) of the detritus per diversity level

higher, respectively, than in Treatments A ( $p<0.01), B$ $(\mathrm{p}<0.001)$ and $\mathrm{C}(\mathrm{p}<0.01)$, and in the 3 -species Treatment L (D. meyli, D. oschei and D. dievengatensis) than in Treatment N (Diplolaimelloides meyli, Panagrolaimus paetzoldi and $D$. dievengatensis $)(\mathrm{p}<0.05)$. These significant differences were confirmed by 2-way ANOVA (overall treatment effect: $F_{10,154}=15.21$, p < 0.001; all mentioned pairwise comparisons: $\mathrm{p}<0.001$ ).

\section{DISCUSSION}

\section{Development of nematode populations}

All 4 nematode species used in this experiment are classified as deposit feeders (Wieser 1953) and are assumed to feed mainly on bacteria (Moens \& Vincx 1997). Despite their similar functional position, some ecological differences between the Panagrolaimidae and Monhysteridae have been described. Panagrolaimidae are enrichment opportunists that quickly colonise organically enriched sites with high microbial activity and disappear as microbial activity decreases (Bongers \& Bongers 1998). Monhysteridae also occur at sites with high resource availability; however, they can persist under food-poor conditions and as such belong to the general opportunists (Bongers et al. 1995). Their generation time is slightly longer in comparison with that of the Panagrolaimidae. Due to these differences, Panagrolaimus paetzoldi was expected to reach peak densities at the start of the experiment, while abundances of monhysterids were expected to increase more slowly, but to persist throughout the experiment. These predictions, however, were not confirmed by our observations; densities of $P$. paetzoldi were much higher during the entire course of the experiment, in both the monospecific and the combination treatments.

Another remarkable observation was that monhysterid densities were considerably lower in the combination treatments compared to the monospecific treat- 
ments. The smaller initial inoculum in the combination treatments compared to the monospecific treatments (36 individuals in the monospecific treatments, compared to 18 and 12 in, respectively, the 2- and 3species combinations) might have caused a delay in the population development of each species. However, this discrepancy should vanish over subsequent generations, as was the case for Panagrolaimus paetzoldi. Moreover, an additional experiment, with larger nematode inocula, confirmed inhibitory interactions between 2 of the monhysterids used here (Diplolaimelloides meyli and Diplolaimella dievengatensis) (I. De Mesel \& S. Derycke pers. obs.).

Similar observations have been reported in previous studies. In those studies, however, the bacterivores differed substantially in their life-history characteristics (comparable to the Panagrolaimidae-Monhysteridae differences in our study) (Ilieva-Makulec 2001, Postma-Blaauw et al. 2005), and inhibition was attributed to competition for limiting resources. Nematode densities in our monospecific treatments show, however, that even when all species require the same bacterial diet, higher densities can be sustained with the available resources. Additionally, a food-selection experiment (Moens et al. 1999) and analysis of the bacterial community in the monospecific treatments (De Mesel et al. 2004) indicated different feeding preferences between (even congeneric) species, which should allow them to partition the available food sources. The similar aerobic activity and even higher proteolytic activity in the combination treatments compared with the monospecific treatments do not support the idea of resource limitation through a suppression of the bacterial community either.

Information on inhibition within benthic fauna is, in general, very scarce, while facilitative interactions between species and their consequences for diversity-ecosystem relationships have been well documented (e.g. David 1996, Levin et al. 2001, Cardinale et al. 2002). Chandler \& Fleeger (1987), however, reported inhibition between copepods in estuarine sediments, which they ascribed to mucus trails secreted by one of the copepod species. This not only altered sediment structure, but might also have evoked chemical repulsion. Many free-living marine nematodes also secrete mucus (Riemann \& Schrage 1978, Riemann \& Helmke 2002). It seems unlikely that any structural modification of the sediment could have caused the mutual suppression in population development because species-specific monhysterid densities were probably too low to substantially affect the sediment structure of the total microcosm. In contrast, chemical cues could emanate from the mucus tracks, or from other glandular secretions. Nematodes are sensitive to chemical signals (Huettel 1986), which are important in reproduction (Bone 1982) or for tracing food (Moens et al. 1999).

\section{Nematode species- and diversity-related effects on microbial activity and bacterial diversity}

The activity of the microbial community was measured by the respiration rate and the proteolytic activity. Respiration rate would mainly represent fungal activity (Padgett et al. 1985). The highest respiration rate was observed in the control and coincided with observations of a stronger growth of fungi compared to nematode treatments (De Mesel et al. 2003). In terrestrial systems an inhibition of fungal growth in the presence of nematodes has been described, either as a consequence of direct grazing effects or through interactions with bacteria (Kaufman et al. 1983, Grewal 1991, Grewal \& Richardson 1991, Grewal \& Hand 1992). Since none of the nematode species used here feed on fungi, we suggest that bacteria-fungi interactions are responsible for the reduced fungal growth in our nematode-containing microcosms. Antagonistic interactions between bacteria and fungi during decomposition of aquatic plant litter have been described (Wohl \& McArthur 2001, Mille-Lindblom \& Tranvik 2003). Nematodes might have caused a shift in the microbial community in favour of bacteria, for instance through secretion of mucus trails (Riemann \& Schrage 1978, Moens et al. 2005), which, in turn, antagonised the development of fungi, thus slowing down the decomposition process (see below).

The effects of nematodes on microbial activity did not show a clear diversity dependence. In the first part of the experiment a slight increase in proteolytic activity-mainly representing bacterial activity (De Mesel et al. 2003) - at higher nematode diversities was present; however, this trend completely disappeared after 30 d. Respiration rate could not be linked with nematode diversity at any time (see De Mesel et al. 2003 for an in-depth interpretation of proteolytic activity versus respiration rate).

On the other hand, species-specific effects did occur. Proteolytic activity was considerably lower in the presence of Panagrolaimus paetzoldi than in the other treatments within the same diversity level. Also, respiration rates were lower in treatments with $P$. paetzoldi; however, this was less pronounced than for proteolytic activity. Densities of $P$. paetzoldi were much higher than those of the monhysterids, so this reduction in microbial activity can possibly be ascribed to overgrazing of the bacterial community (De Mesel et al. 2003) rather than to species-specific effects. Since nematodes were not removed from the suspension before measuring microbial activity, some 
effect of nematode activity on the obtained results cannot be excluded, especially in the presence of the high numbers of $P$. paetzoldi. The effect of the low densities of the Monhysteridae was presumably negligible. A correction for the impact of $P$. paetzoldi on the activity measurements, however, will emphasise their negative effect on microbial activity even more.

Not only bacterial activity, but also bacterial diversity was reduced in the presence of Panagrolaimus paetzoldi (see also De Mesel et al. 2004). While, in general, a positive trend in the relationship between number of nematode species and enzymatic activity was seen, the link with bacterial diversity was negative. This implies a lack of correlation between bacterial diversity and bacterial activity, an observation that has been previously reported (Troussellier et al. 2002).

\section{Nematode species- and diversity-related effects on decomposition rates}

Despite the low nematode densities in the absence of Panagrolaimus paetzoldi and the dominance of the latter species when present, we did find a diversityrelated effect on the $\mathrm{C}$ content of the cordgrass detritus. In the monospecific treatments, $\mathrm{C}$ content was higher than in the controls, indicating a slower decomposition rate (see also De Mesel et al. 2003). An even more severe suppression of C-loss rates occurred when 2 nematode species were pooled, but at the 3 -species diversity level $\mathrm{C}$ loss rates were again comparable to the monospecific treatments, or even higher, as for the treatment with $P$. paetzoldi, Diplolaimella dievengatensis and Diplolaimelloides meyli. The reason for this, however, remains unclear.

$\mathrm{N}$ content of the cordgrass leaves was generally lowest in the control treatment. Nematodes consume nitrogen in excess when feeding on bacteria (Anderson et al. 1983, Ferris et al. 1997). After excretion, this nitrogen can be used by the microbiota or adsorbed to the detritus (White \& Howes 1994, Valiela 1995), masking any effect of microbial activity on the removal of nitrogen.

Although significant differences in $\mathrm{N}$ content of the cordgrass leaves between nematode treatments were found, no link with particular species or species combinations could be made. For instance, in the presence of only Diplolaimelloides meyli or only Diplolaimella dievengatensis, $\mathrm{N}$ content was significantly higher than in the control treatment, but when these 2 species were pooled, the difference from the control was less pronounced; adding a third monhysterid (Diplolaimelloides oschei) again yielded a significantly higher $\mathrm{N}$ content than in the control.

No link between bacterial diversity and decomposition rates was found. According to O'Donnell et al. (2001), the central problem in microbial ecology is to understand the link between genetic diversity and community structure, and between community structure and function. Studies on functional implications of altering microbial diversity in soil systems are still scarce; however, a considerable degree of redundancy is expected (Griffiths et al. 2000, Nannipieri et al. 2003). Differences in C-use efficiencies between bacterial communities might also have affected our results (Degens 1998, and references therein). Additionally, Riemann \& Helmke (2002) suggested that nematodes and bacteria growing on their mucus tracks, 'share' enzymes to break down organic matter. This way, nematodes could directly assimilate organic compounds from the detritus.

\section{CONCLUSIONS}

The main aim of the present study was to evaluate the importance of nematode species and diversity in affecting the microbial activity and organic matter decomposition rate. Our data did not support any hypothesis predicting enhancement of process rates with an (initial) increase in species numbers, as for instance in the rivet hypothesis (Ehrlich \& Ehrlich 1981). A key mechanism in enhancing ecosystem function would be interspecific facilitation (Fridley 2001, Loreau \& Hector 2001, Mulder et al. 2001, Cardinale et al. 2002). Facilitation between nematodes was not observed in our experiments; instead, we found clear evidence of inhibitory interaction between the closely related monhysterid species.

The null hypothesis and the modified null hypothesis (Schläpfer et al. 1999) were not supported by our results either, because: (1) nematodes did affect decomposition rate and microbial activity and (2) considerable and often significant differences were found between treatments and diversity levels.

Redundancy among the monhysterids seems unlikely, since they affected several parameters differently. For instance, $\mathrm{N}$ loss was very different between treatments with different monhysterid species. Differences between the treatments with monhysterids and those with Panagrolaimus paetzoldi were obvious. The extremely high densities of $P$. paetzoldi resulted in a reduction in bacterial activity and diversity; however, this did not translate into a slower decomposition rate. In addition, in the treatments exclusively containing monhysterid nematode species, no clear link between microbial activity and decomposition rate was found.

Our results support the idiosyncratic diversity model, which describes an unpredictable effect of changing species composition or species diversity on ecosystem processes. However, in agreement with Mikola \& Setälä (1998) and Postma-Blaauw et al. (2005), who 
also found an idiosyncratic response of microbivore nematode diversity in terrestrial soil systems, we should note that our experiments contained small numbers of species. It is possible that idiosyncratic effects are mainly visible in low-diversity systems. However, several other experimental studies, using other benthic systems, have confirmed this idiosyncratic theory (e.g. Emmerson et al. 2001, Downing \& Leibold 2002).

Acknowledgements. A. Van Kenhove is acknowledged for the chemical analyses and Prof. Dr. J. Vanfleteren for the use of the Victor Multilabel counter. We thank Prof. Dr. A. Vanreusel, Dr. P. Herman and Dr. M. De Troch for their valuable comments on the manuscript. I.D.M. aand S.D. acknowledge grants from the Flemish Institute for the Promotion of Scientific-Technological Research (I.W.T.). T.M. is a postdoctoral fellow with the Flemish Fund for Scientific Research. Further financial support was obtained from Ghent University, BOF Projects 1205398 and 011060002.

\section{LITERATURE CITED}

Alkemade R, Wielemaker A, de Jong SA, Sandee AJJ (1992a) Experimental evidence for the role of bioturbation by the marine nematode Diplolaimella dievengatensis in stimulating the mineralization of Spartina anglica detritus. Mar Ecol Prog Ser 90:149-155

Alkemade R, Wielemaker A, Hemminga MA (1992b) Stimulation of Spartina anglica leaves by the bacterivorous marine nematode Diplolaimelloides bruciei. J Exp Mar Biol Ecol 159:267-278

Alkemade R, Wielemaker A, Hemminga MA (1993) Correlation between nematode abundance and decomposition rate of Spartina anglica leaves. Mar Ecol Prog Ser 99:293-300

Anderson RV, Gould WD, Woods LE, Cambardella C, Ingham RE, Coleman DC (1983) Organic and inorganic nitrogenous losses by microbivorous nematodes in soil. Oikos 40 : 75-80

Bone LW (1982) Reproductive chemical communication of helminthes. II. Aschelminthes. Int J Invertebr Reprod 5: 311-321

Bongers T, Bongers M (1998) Functional diversity of nematodes. Appl Soil Ecol 10:239-251

Bongers T, de Goede RGM, Korthals GW, Yeates GW (1995) Proposed changes of c-p classification for nematodes. Russ J Nematol 3:61-62

Cardinale BJ, Palmer MA, Collins SL (2002) Species diversity enhances ecosystem functioning through interspecific facilitation. Nature 415:426-429

Chandler GT, Fleeger JW (1987) Facilitative and inhibitory interactions among estuarine meiobenthic harpacticoid copepods. Ecology 68:1906-1919

David AR (1996) Association among ascidians: facilitation of recruitment in Pyura spinifera. Mar Biol 126:34-41

Degens BP (1998) Decreases in microbial functional diversity do not result in corresponding changes in decomposition under different moisture conditions. Soil Biol Biochem 30: $1989-2000$

De Mesel I, Derycke S, Swings J, Vincx M, Moens T (2003) Influence of bacterivorous nematodes on the decomposition of cordgrass. J Exp Mar Biol Ecol 296:227-242
De Mesel I, Derycke S, Moens T, Van der Gucht K, Vincx M, Swings J (2004) Top-down impact of bacterivorous nematodes on the bacterial community structure: a microcosm study. Environ Microbiol 6:733-744

Dietrich G, Kalle K (1957) Allgemeine Meereskunde. Eine Einführung in die Ozeanographie. Gebrüder Borntraeger, Berlin

Downing AL, Leibold MA (2002) Ecosystem consequences of species richness and composition in pond food webs. Nature 416:837-841

Ehrlich PR, Ehrlich AH (1981) Extinction. The causes and consequences of the disappearance of species. Random House, New York

Emmerson MC, Solan M, Emes C, Paterson DM, Rafaelli D (2001) Consistent patterns and the idiosyncratic effects of biodiversity in marine ecosystems. Nature 411:73-77

Ferris H, Venette RC, Lau SS (1997) Population energetics of bacterial-feeding nematodes: carbon and nitrogen budgets. Soil Biol Biochem 29:1183-1194

Findlay S, Tenore KR (1982) Effect of a free-living marine nematode (Diplolaimella chitwoodi) on detrital carbon mineralization. Mar Ecol Prog Ser 8:161-166

Freckman DW (1988) Bacterivorous nematodes and organic matter decomposition. Agric Ecosyst Environ 24:195-217

Fridley JD (2001) The influence of species diversity on ecosystem productivity: How, where, and why? Oikos 93: 514-526

Grewal PS (1991) Relative contribution of nematodes (Caenorhabditis elegans) and bacteria towards the disruption of flushing patterns and losses in yield and quality of mushrooms (Agaricus bisporus). Ann Appl Biol 119: 438-499

Grewal PS, Hand P (1992) Effects of bacteria isolated from a saprophagous rhabditid nematode Caenorhabditis elegans on mycelial growth of Agaricus bisoporus. J Appl Bacteriol 72:173-179

Grewal PS, Richardson PN (1991) Effects of Caenorhabditis elegans (Nematoda: Rhabditidae) on yield and quality of the cultivated mushroom Agaricus bisporus. Ann Appl Biol 118:381-394

Griffiths BS (1994) Microbial-feeding nematodes and Protozoa in soil: their effects on microbial activity and nitrogen mineralization in decomposition hotspots and the rhizosphere. Plant Soil 164:25-33

Griffiths BS, Ritz K, Bardgett RD, Cook R and 8 others (2000) Ecosystem response of pasture soil communities to fumigation induced microbial diversity reductions: an examination of the biodiversity-ecosystem function relationship. Oikos 90:279-294

Heip C, Vincx M, Vranken G (1985) The ecology of marine nematodes. Oceanogr Mar Biol Annu Rev 23:399-489

Howarth RW (1993) Microbial processes in salt-marsh sediments. In: Ford TE (ed) Aquatic microbiology. An ecological approach. Blackwell Scientific Publications, Boston, MA, p 239-259

Huettel RN (1986) Chemical communicators in nematodes. J Nematol 18:3-8

Ilieva-Makulec K (2001) A comparative study of the life strategies of two bacterial-feeding nematodes under laboratory conditions. II. Influence of the initial food level on the population dynamics of Acrobeloides nanus (De Man, 1880) Anderson, 1968 and Dolichorhabditis dolichura (Schneider, 1866) Andrássy, 1983. Pol J Ecol 49:123-135

Kaufman TD, Bloom JR, Lukezic FL (1983) Effect of an extract from saprozoic nematode-infested compost on the mycelial growth of Agaricus brunnescens. J Nematol 15: $567-571$ 
Lawton JH (1994) What do species do in ecosystems? Oikos 71:367-374

Levin LA, Boesch DF, Covich A, Dahm C and 8 others (2001) The function of marine critical transition zones and the importance of sediment biodiversity. Ecosystems 4: $430-451$

Loreau M, Hector A (2001) Partitioning selection and complementarity in biodiversity experiments. Nature 412:72-76

Loreau M, Naeem S, Inchausti P, Bengtsson J and 8 others (2001) Biodiversity and ecosystem functioning: current knowledge and future challenges. Science 294:804-808

Magurran AE (1988) Ecological diversity and its measurement. Princeton University Press, Princeton, NJ

Mamilov AS, Byzov BA, Pokarzhevskii AD, Zvyagintsev DG (2000) Regulation of the biomass and activity of soil microorganisms by microfauna. Microbiology 69:612-621

Mikola J, Setälä H (1998) Relating species diversity to ecosystem functioning: mechanistic backgrounds and experimental approach with a decomposer food web. Oikos 83: 180-194

Mille-Lindblom C, Tranvik LJ (2003) Antagonism between bacteria and fungi on decomposing aquatic plant litter. Microb Ecol 45:173-182

Moens T, Vincx M (1997) Observations on the feeding ecology of estuarine nematodes. J Mar Biol Assoc UK 77: 211-227

Moens T, Vincx M (1998) On the cultivation of free-living marine and estuarine nematodes. Helgol Meeresunters 52:115-139

Moens T, Verbeeck L, de Maeyer A, Swings J, Vincx M (1999) Selective attraction of marine bacterivorous nematodes to their bacterial food. Mar Ecol Prog Ser 176:165-178

Moens T, dos Santos GAP, Thompson F, Swings J, FonsêcaGenevois V, Vincx M, De Mesel I (2005) Do nematode mucus secretions affect microbial growth? Aquat Microb Ecol 40:77-83

Mulder CPH, Uliassi DD, Doak DF (2001) Physical stress and diversity-productivity relationships: the role of positive interactions. Proc Natl Acad Sci USA 98:6704-6708

Naeem S (1998) Species redundancy and ecosystem reliability. Conserv Biol 12:39-45

Nannipieri P, Ascher J, Ceccherini MT, Landi L, Pietramellara G, Renella G (2003) Microbial diversity and soil functions. Eur J Soil Sci 54:655-670

O'Donnell AG, Seasman M, Macrae A, Waite I, Davies JT (2001) Plants and fertilizers as drivers of change in micro-

Editorial responsibility: Lisa Levin (Contributing Editor), La Jolla, California, USA bial community structure and function in soils. Plant Soil 232:135-145

Padgett DE, Courtney TH, Sizemore RK (1985) A technique for distinguishing between bacterial and non-bacterial respiration in decomposing Spartina alterniflora. Hydrobiologia 112:113-119

Postma-Blaauw MB, de Vries FT, de Goede RGM, Bloem J, Faber JH, Brussaard L (2005) Within-trophic group interactions of bacterivorous nematode species and their effects on the bacterial community and nitrogen mineralization. Oecologia 142:428-439

Riemann F, Helmke E (2002) Symbiotic relations of sedimentagglutinating nematodes and bacteria in detrital habitats: the enzyme-sharing concept. PSZN I: Mar Ecol 23:93-113

Riemann F, Schrage M (1978) The mucus-trap hypothesis on feeding of aquatic nematodes and implications for biodegradation and sediment texture. Oecologia 34:75-88

Schläpfer F, Schmid B, Seidl I (1999) Expert estimates about effects of biodiversity on ecosystem processes and services. Oikos 84:346-352

Tilman D, Reich PB, Knops J, Wedin D, Mielke T, Lehman C (2001) Diversity and productivity in a long-term grassland experiment. Science 294:843-845

Troussellier M, Schafer H, Batailler N, Bernard L and 5 others (2002) Bacterial activity and genetic richness along an estuarine gradient (Rhone River plume, France). Aquat Microb Ecol 28:13-14

Valiela I (1995) Marine ecological processes. Springer-Verlag, New York

Walker BH (1992) Biodiversity and ecological redundancy. Conserv Biol 6:18-23

Walker BH (1995) Conserving biological diversity through ecosystem resilience. Conserv Biol 9:747-752

Warwick RM (1987) Meiofauna: their role in marine detrital systems. Detritus and microbial ecology in aquaculture. ICLARM Conf Proc 14:282-295

White DS, Howes BL (1994) Nitrogen incorporation into decomposing litter of Spartina alterniflora. Limnol Oceanogr 39:133-140

Wieser W (1953) Die Beziehung zwischen Mundhöhlengestalt, Ernährungsweise und Vorkommen bei freilebenden marinen Nematoden. Eine ökologische-morphologische Studie. Ark Zool 4:439-484

Wohl DL, McArthur JV (2001) Aquatic actinomycete-fungal interactions and their effects on organic matter decomposition: a microcosm study. Microb Ecol 42:446-457

Submitted: September 29, 2005; Accepted: February 28, 2006 Proofs received from author(s): August 7, 2006 